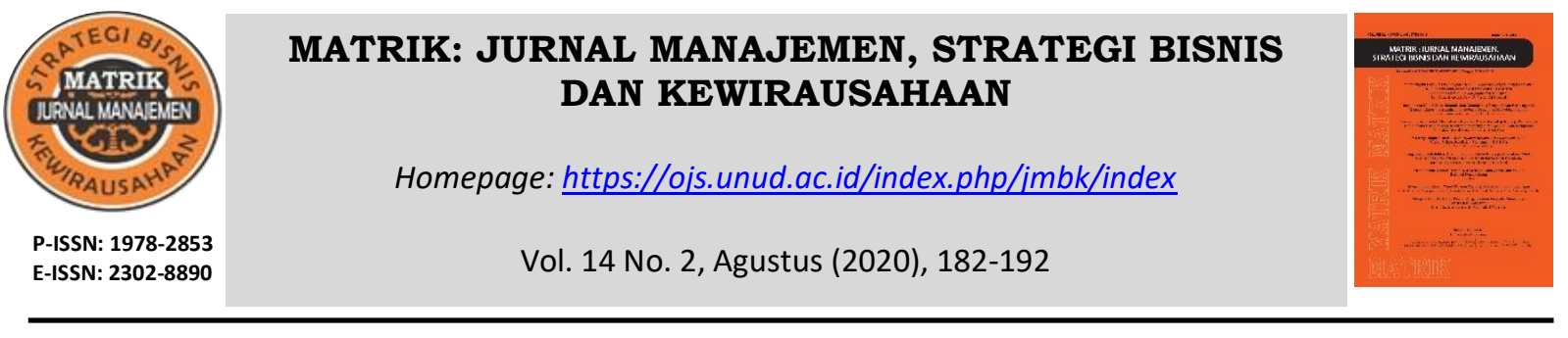

\title{
Kinerja Sosial Lembaga Perkreditan Desa
}

I Gde Kajeng Baskara ${ }^{1)}$, Nyoman Triaryati ${ }^{2}$

1,2 Fakultas Ekonomi dan Bisnis Universitas Udayana email: kajengbaskara@unud.ac.id

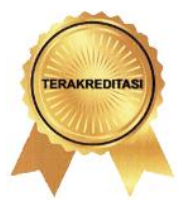

SINTA 2

DOI : https://doi.org/10.24843/MATRIK:JMBK.2020.v14.i02.p05

\begin{abstract}
ABSTRAK
Penelitian ini bertujuan untuk mengukur kinerja sosial Lembaga Perkreditan Desa. Kinerja LPD tidak hanya dilihat dari kinerja secara finansial, namun lebih dari itu kinerja sosial mutlak untuk dinilai. Kinerja sosial LPD diukur dengan empat dimensi menggunakan Social Performance Indicators. Dimensi ini antara lain 1) dimensi sasaran dan jangkauan, 2) produk dan layanan, 3) manfaat bagi anggota serta 4) dimensi tanggungjawab sosial. Populasi penelitian ini adalah 38 LPD dengan klasifikasi kekayaan diatas Rp 100 Milyar (>100 M), dengan metode sampling menggunakan metode sensus. Hasil penelitian menunjukkan kinerja sosial LPD besar di Bali sangat lemah pada dimensi sasaran dan jangkauan namun kuat pada dimensi tanggung jawab sosial. Kriteria metode pro-poor dan sasaran individu merupakan kriteria dengan kinerja sosial paling lemah. LPD harus juga memfokuskan programnya pada masyarakat miskin. Hal ini dapat dilakukan dengan cara menjalin kerjasama dengan LPD yang ada di wilayah dengan masyarakat miskin yang masih cukup tinggi.
\end{abstract}

Kata kunci: kinerja sosial, lembaga keuangan mikro, lembaga perkreditan desa

\section{Social Performance of The Village Credit Institution}

\begin{abstract}
This research aims to measure the social performance of Village Credit Institutions (VCI). VCI performance is not only seen from financial performance, but the social performance has also need to be assessed. The social performance management is measured by four dimension using the Social Performance Indicators. These dimensions include 1) target and outreach, 2) products and services, 3) benefits for the members and 4) social responsibility. The population of this study includes $38 \mathrm{VCI}$ with total asset above Rp100 billion (> Rp $100 \mathrm{M}$ ) as the census technique was applied, all VCI was taken as the sample. The results show that the social performance of large VCI in Bali is very weak on target and outreach dimension but is strong on social responsibility. The propoor method and the individuals targeting are the weakest social performance criteria. These institutions must also focus their programs on helping the poor people. This can be done by collaborating with other institutions located in the areas with high poverty rates.
\end{abstract}

Keyword: social performance, microfinance, village credit institutions

\section{PENDAHULUAN}

Lembaga keuangan mikro merupakan salah satu pilar dalam proses intermediasi keuangan. Lembaga Keuangan Mikro (LKM) jika mengacu pada Undang Undang No.1 tahun 2013 tentang Lembaga Keuangan Mikro didefinisikan sebagai lembaga keuangan yang khusus 
didirikan untuk memberikan jasa pengembangan usaha dan pemberdayaan masyarakat, baik melalui pinjaman atau pembiayaan dalam usaha skala mikro kepada anggota dan masyarakat, pengelolaan simpanan, maupun pemberian jasa konsultasi pengembangan usaha yang tidak semata-mata mencari keuntungan. Definisi tersebut menyiratkan bahwa LKM merupakan sebuah institusi profit motive yang juga bersifat social motive, yang kegiatannya lebih bersifat community development dengan tanpa mengesampingkan perannya sebagai lembaga intermediasi keuangan (Baskara, 2013).

Selama ini motif sosial LKM jarang diukur dan dinilai dengan menggunakan indikator penilaian kinerja yang tepat. Kinerja LKM hanya diukur berdasarkan pencapaian kinerja keuangan. Kondisi ini tentunya berimbas pada kinerja sosial yang tidak terukur dengan baik dan fungsi sosial dengan evaluasi yang tidak optimal. Hal ini terutama disebabkan oleh tidak adanya sasaran kinerja sosial yang formal dan terukur. Manajemen LKM tidak menyertakan sasaran sosial dalam penyusunan rencana dan target kerja. Pengukuran social performance indicators dapat menjadi acuan dalam melakukan penilaian kinerja sosial serta membantu LKM dalam mengoptimalkan fungsi sosialnya. Fungsi sosial LKM yang terimplementasi dengan baik akan berimbas pada peningkatan kesejahteraan masyarakat dan berperan besar pada pengentasan kemiskinan (Bibi et al., 2018).

Pengukuran kinerja sosial LKM tidak hanya digunakan oleh pihak eksternal namun yang paling penting adalah bagi LKM itu sendiri. Pengukuran kinerja sosial dapat menjadi acuan dasar bagi lembaga keuangan ini dalam merumuskan kebijakan dan arah organisasi dalam upaya mengoptimalkan fungsi sosial yang diembannya. Sebagai sebuah lembaga intermediasi keuangan, optimalisasi peran sosial ini tentunya akan berdampak besar pada peningkatan taraf hidup masyarakat di wilayah LKM itu sendiri.

Lembaga Perkreditan Desa (LPD) di Bali merupakan LKM yang memiliki keunikan tersendiri. LPD tidak dikategorikan sebagai lembaga keuangan mikro dalam aturan pemerintah pusat karena kepemilikan dan pengelolaan LPD yang memiliki kekhususan dalam aspek budaya dan religi serta hukum adat formal yang hanya berlaku di daerah Bali. Dalam Peraturan Daerah Provinsi Bali Nomor 3 Tahun 2017, LPD didefinisikan sebagai lembaga keuangan milik Desa Pakraman yang berkedudukan di wewidangan Desa Pakraman. Desa Pakraman merupakan kesatuan masyarakat hukum adat di Bali yang memiliki kesatuan tradisi dan tata krama berdasarkan budaya Bali dan agama Hindu. Seperti LKM yang lain, LPD juga memiliki fungsi dan motif sosial. Fungsi sosial inilah yang selama ini tidak pernah dilakukan pengukuran secara komprehensif.

Dari perspektif keuangan mikro, kinerja sosial atau social performance didefinisikan sebagai penterjemahan misi sosial yang efektif dari sebuah institusi ke dalam praktik yang sesuai dengan nilai sosial yang diterima umum. Dengan kata lain, kinerja sosial adalah menyangkut keberhasilan dalam pencapaian misi sosial organisasi (CGAP, 2007). Untuk mencapai kinerja sosial yang baik, LKM harus mengelola kinerja sosialnya dengan penuh perhatian dan mengintegrasikannya dengan kinerja keuangan.

Penelitian terkait topik pengukuran kinerja LKM didominasi oleh laporan dari institusi dunia tentang pengukuran kinerja LKM pada cakupan wilayah negara atau nasional. Perkembangan indikator yang digunakan dalam pengukuran kinerja sosial menjadi bidang kajian yang banyak dilakukan. Teknik penilaian kinerja LKM telah dikembangkan sejak tahun 1990-an. Sebuah lembaga internasional bernama ACCION yang memiliki misi pengentasan kemiskinan di Afrika, mengembangkan metode CAMEL untuk mengevaluasi lembagalembaga pemberi pinjaman komersial di Amerika Serikat. Pada tahun 2001, World Council of Credit Union (WOCCU) sebuah organisasi nirlaba yang mendorong pengembangan kerja sama keuangan, menggunakan model PEARLS dalam menilai kinerja LKM. Model PEARLS 
merupakan satu set rasio yang terdiri dari 45 rasio yang digunakan untuk mengevaluasi dan memonitor stabilitas keuangan serikat kredit dalam WOCCU, terutama digunakan dalam pengembangan institusional. PEARLS merupakan singkatan dari protection, effective financial structure, asset quality, rate of return, liquidity dan sign of growth (Arsyad, 2008).

Sebuah lembaga nirlaba internasional yang berbasis di Paris Perancis bernama PlaNet Finance mengembangkan metode GIRAFE dalam menilai kinerja LKM. Indikator yang digunakan berjumlah 26 dan digolongkan ke dalam 6 wilayah risiko, yakni; (1) proses pengambilan keputusan dan tata kelola, (2) instrumen manajemen dan informasi, (3) analisis dan kendali risiko, (4) aset-aset termasuk portofolio pinjaman, (5) pembiayaan, dan (6) efisiensi dan tingkat keuntungan.

Pendekatan pengukuran kinerja LKM berikutnya dikembangkan oleh MicroRate, sebuah lembaga pemeringkatan microfinance yang berpusat di Washington, Amerika Serikat. MicroRate menggunakan metodologi yang berfokus pada berbagai macam risiko pada operasional lembaga-lembaga keuangan yang mempengaruhi kelayakan kredit suatu lembaga. Komponen utama pada metode Microrate ini adalah: (1) mengenali wilayah-wilayah risiko utama dan penggeraknya; (2) membandingkan kinerja LKM dengan LKM lain (3) ketersediaan informasi. Faktor-faktor utama yang menjadi fokus penilaian adalah efisiensi, kualitas aset, pertumbuhan dan tingkat keuntungan.

Sebuah model pengukuran yang dikembangkan oleh CERISE, mengistilahkan penilaian kinerja LKM sebagai sebuah audit sosial dan keuangan. CERISE adalah lembaga nirlaba yang didirikan di Prancis pada tahun 1998 yang bertujuan untuk mengembangkan riset dan inovasi dalam bidang keuangan mikro. CERISE merupakan gabungan dari empat institusi keuangan mikro Prancis yakni CIDR, GRET, IRAM dan Montpellier Supagro. Model pengukuran yang dikembangkan CERISE adalah Social Performance Indicators (SPI) yang mengkhususkan audit kinerja sosial dari LKM.

Terdapat empat dimensi pengukuran kinerja sosial pada pengukuran model SPI ini yakni (1) target dan jangkauan, (2) produk dan jasa, (3) manfaat pada klien, dan (4) tanggung jawab sosial. Keempat dimensi ini kemudian dikembangkan dan direklasifikasi pada model SPI4 menjadi 6 dimensi yakni; (1) target sosial, (2) komitmen manajemen pada target sosial, (3) produk, jasa dan saluran distribusi, (4) tanggung jawab pada klien, (5) tanggung jawab pada karyawan, (6) keselarasan kinerja sosial dan keuangan. Penelitian yang dilakukan Amersdorffer et al (2015) mengukur kinerja sosial koperasi pertanian di Bulgaria dengan menggunakan model SPI ini dalam upaya mengukur efisiensi kinerja sosial. Nieto et al (2007) mengukur efisiensi sosial LKM diseluruh dunia dan menemukan pentingnya pengukuran kinerja sosial dalam upayya membandingkan dengan efisiensi kinerja keuangan LKM.

Selama ini kinerja LPD hanya dilihat dari aspek keuangan. Kinerja keuangan LKM biasanya diukur dengan menggunakan metode CAMEL (Capital, Asset, Management, Earning dan Liquidity). LPD di Bali juga menggunakan CAMEL dalam mengevaluasi kinerja keuangan melalui penilaian tingkat kesehatan. Sundarianingsih (2014) mengukur kinerja keuangan LPD Pekutatan dan menemukan bahwa kinerja keuangan LPD yang sehat dapat mendukung sosial ekonomi masyarakat desa adat. Kinerja sosial LPD pada penelitian ini akan diukur dengan menggunakan Social Performance Indicators (SPI). Dengan mengetahui kinerja sosial lembaga adat ini maka peran sosial lembaga ini khususnya bagi masyarakat adat di Bali dapat terukur dengan baik. Hasil pengukuran kinerja sosial ini sangat penting dalam mengevaluasi program dan menentukan arah kebijakan LPD selanjutnya agar fungsi sosialnya dapat dikembangkan secara maksimal.

\section{METODE PENELITIAN}


Berdasarkan data akhir tahun 2017 diketahui terdapat 1.433 LPD di seluruh Bali. Dari jumlah tersebut sebanyak 150 LPD dinyatakan tidak beroperasi. Secara keseluruhan, total kekayaan LPD mencapai Rp. 18 Trilyun. Peringkat kekayaan LPD dinilai dari total aktiva atau total aset yang dimilikinya. Klasifikasi peringkat kekayaan LPD disajikan pada Tabel 1, dimana peringkat kekayaan dibagi menjadi tujuh peringkat. Peringkat tertinggi atau kelompok tertinggi adalah lembaga dengan total kekayaan diatas Rp 100 Milyar (>100 M) dan peringkat atau kelompok terendah adalah LPD dengan total kekayaan dibawah Rp 100 Juta (<100 Jt).

Data pada Tabel 1 menunjukkan jumlah lembaga dengan peringkat kekayaan terbesar atau diatas Rp 100 Milyar sebanyak 38 LPD dengan total kekayaan mencapai Rp 7,6 Trilyun. Kelompok ini tercatat memiliki total kekayaan 41,44\% dari total kekayaan seluruh LPD. Kelompok inilah yang menjadi populasi penelitian ini. Populasi ini dipilih karena keterbatasan waktu penelitian, banyaknya jumlah dan luasnya sebaran LPD di Provinsi Bali. Fokus pada kelompok LPD besar ini juga dilatarbelakangi oleh manajemen pengelolaan yang lebih baik sehingga memudahkan dalam proses pengumpulan data. Selain itu program-program sosial juga banyak terdapat pada LPD kelompok besar ini. Penelitian ini menggunakan pendekatan kualitatif dan kuantitatif deskriptif. Metode kualitatif digunakan dalam mengembangkan kuesioner SPI dan hasil interview yang digunakan dalam penyusunan indikator penilaian kinerja sosial. Metode kuantitatif dibutuhkan dalam mengukur dan mengkuantifikasi hasil kuesioner kinerja sosial menjadi skor nilai kinerja sosial.

Kinerja sosial merupakan penterjemahan misi sosial yang efektif dari sebuah institusi ke dalam praktik yang sesuai dengan nilai sosial yang diterima umum. Kinerja sosial adalah menyangkut keberhasilan dalam pencapaian misi sosial organisasi. Kinerja sosial ini diukur dengan menggunakan Social Performance Indicators (SPI) audit tools yang mengukur empat dimensi kinerja yakni: Dimensi Sasaran dan Jangkauan, Dimensi Produk dan Layanan, Dimensi Manfaat bagi Anggota/Nasabah serta Dimensi Tanggungjawab Sosial. Pada tiap dimensi terdapat tiga kriteria yang merupakan indikator pengukuran masing-masing dimensi. Masing-masing kriteria berisikan lima hingga tujuh pertanyaan dengan skor 0 hingga 2. Secara keseluruhan model pengukuran ini terdiri dari empat dimensi dengan 12 kriteria dan total 71 pertanyaan. Maksimal skor yang dapat dicapai oleh LPD adalah 102 poin.

Pengumpulan data dilakukan melalui kuesioner dan wawancara. Terdapat dua metode pendekatan dalam pengumpulan data model pengukuran kinerja sosial ini. Pendekatan pertama adalah centralized approach yang merupakan pendekatan yang melibatkan manajemen puncak LPD dengan dibantu oleh tim peneliti, pendekatan ini dapat menghemat waktu dan biaya. Pendekatan kedua adalah participatory approach dimana pendekatan ini melibatkan berbagai level manajemen, baik staf, kepala cabang dan juga manajemen puncak. Dalam model pendekatan kedua ini tim peneliti tetap melakukan pendampingan. Pendekatan kedua ini membutuhkan waktu dan biaya yang lebih besar.

Pendekatan yang digunakan dalam penelitian ini adalah centralized approach dengan hanya melibatkan pengurus serta panureksa LPD serta didampingi tim peneliti. Pengumpulan data dilakukan dengan pemberian kuesioner pengukuran kinerja sosial yang sudah dikembangkan serta wawancara baik secara perseorangan maupun melalui focus group discussion (FGD).

Metode analisis yang digunakan adalah analisis deskripsi dengan statistik deskriptif untuk menjelaskan hasil pengukuran kinerja sosial. Analisis ini bertujuan untuk menginterpretasikan skor kinerja sosial yang diperoleh dari hasil kuesioner. Skor akan dianalisis pada masing-masing dimensi kinerja dan juga kriteria yang ada pada tiap dimensi hingga kekuatan dan kelemahan kinerja sosial LPD dapat dilihat secara lebih mendalam. 


\section{HASIL DAN PEMBAHASAN}

Peringkat kekayaan LPD dinilai dari nilai total aktiva atau total aset yang dimilikinya. Klasifikasi peringkat kekayaan LPD disajikan pada Tabel 1. Peringkat kekayaan dibagi menjadi tujuh peringkat. Peringkat tertinggi atau kelompok tertinggi adalah lembaga dengan total kekayaan diatas Rp 100 Milyar $(>100 \mathrm{M})$ dan peringkat atau kelompok terendah LPD dengan total kekayaan dibawah Rp 100 Juta $(<100 \mathrm{Jt})$. Berdasarkan data pada Tabel 1 tersebut, LPD dengan peringkat kekayaan terbesar atau diatas Rp 100 Milyar tercatat sejumlah 38 lembaga dengan total kekayaan sekitar Rp 7,6 Trilyun. Kelompok ini tercatat memiliki total kekayaan 41,44\% dari total kekayaan seluruh LPD. Kelompok inilah yang menjadi populasi penelitian ini. Kelompok dengan total kekayaan juga cukup besar yakni 30,80\% dari total kekayaan LPD adalah kelompok lembaga dengan peringkat kekayaan >10 Milyar hingga <50 Milyar rupiah (>10 M - <50 M) yang berjumlah $250 \mathrm{LPD}$.

Secara umum terjadi ketimpangan kekayaan yang cukup besar antar LPD di Bali. Kelompok LPD dengan peringkat kekayaan lebih kecil dari Rp 10 Milyar $(<10 \mathrm{M})$ mencapai 1.099 lembaga dengan total kekayaan hanya Rp 2,5 Trilyun atau hanya $13,71 \%$ dari total kekayaan seluruh LPD namun mencapai $76,69 \%$ dari keseluruhan jumlah LPD. Jika dibandingkan dengan jumlah LPD dengan kekayaan diatas Rp 10 Milyar (>10 M) yang sebanyak 334 lembaga dengan total kekayaan mencapai Rp 15,9 Trilyun atau 86,29\% dari total kekayaan namun hanya merupakan 23,3\% dari jumlah LPD di Bali. Dari kondisi ini dapat disimpulkan bahwa hanya 23,3\% LPD di Bali menguasai 86,29\% total kekayaan LPD.

Tabel 1. Peringkat Kekayaan LPD per Tahun 2017 (dalam ribuan rupiah)

\begin{tabular}{|c|c|c|c|}
\hline $\begin{array}{c}\text { Peringkat } \\
\text { Kekayaan LPD }(\mathbf{R p})\end{array}$ & $\begin{array}{c}\text { Jumlah } \\
\text { Total Asset (Rp) }\end{array}$ & Jumlah LPD & Persentase $(\%)$ \\
\hline$>100 \mathrm{M}$ & 7.654 .697 .801 & 38 & 41,44 \\
\hline$>50 \mathrm{M}-<100 \mathrm{M}$ & 2.595 .444 .746 & 38 & 14,05 \\
\hline$>10 \mathrm{M}-<50 \mathrm{M}$ & 5.689 .761 .991 & 258 & 30,80 \\
\hline$>5 \mathrm{M}-<10 \mathrm{M}$ & 1.310 .647 .306 & 180 & 7,10 \\
\hline$>1 \mathrm{M}-<5 \mathrm{M}$ & 1.088 .931 .929 & 406 & 5,90 \\
\hline$>100 \mathrm{Jt}-<1 \mathrm{M}$ & 128.616 .094 & 281 & 0,70 \\
\hline$<100 \mathrm{Jt}$ & 3.839 .411 & 232 & 0,02 \\
\hline Jumlah & 18.471.939.278 & 1.433 & 100,00 \\
\hline
\end{tabular}

Sumber: LPLPD Provinsi Bali, 2018

Ketimpangan ini terjadi karena LPD yang besar banyak didukung oleh wilayah adat yang merupakan juga wilayah operasional mereka. Wilayah ini berada pada wilayah konsentrasi industri pariwisata (industri andalan Provinsi Bali) yakni Kabupaten Badung, Kota Denpasar dan Kabupaten Gianyar (khususnya wilayah Ubud dan sekitarnya). Kondisi ini harus menjadi perhatian pemangku kepentingan LPD. Pemerataan perkembangan LPD dapat ditingkatkan dengan lebih mengaktifkan peran Badan Kerja Sama LPD (BKS-LPD) dalam menjembatani kerjasama antara LPD besar dan kecil. Kerjasama dapat dilakukan melalui mekanisme kerjasama produk dan layanan baik pinjaman maupun produk lainnya serta penguatan kompetensi manajemen kelembagaan.

Kondisi eksisting LPD per tahun 2017 disajikan pada Tabel 2. Berdasarkan data akhir tahun 2017 terdapat 1.433 LPD di seluruh Bali. Dari jumlah tersebut sebanyak 150 LPD dinyatakan tidak beroperasi. Total kekayaan LPD di Bali pada tahun 2017 mencapai Rp. 18 Trilyun. Sebanyak 73,99\% total kekayaan tersebut dimiliki oleh LPD dengan klasifikasi sehat. Berdasarkan klasifikasi tingkat kesehatan, terdapat 865 LPD yang sehat atau 60,36\% dari keseluruhan LPD, sebanyak 241 lembaga tergolong cukup sehat (16,82\%). Lembaga yang 
kurang sehat, tidak sehat dan tidak beroperasi jika ditotal adalah sebanyak 327 lembaga atau sebesar $22,82 \%$ dari 1.433 LPD.

Tabel 2. Kondisi Eksisting LPD per Tahun 2017

\begin{tabular}{llrrrrr}
\hline No & $\begin{array}{c}\text { Tingkat } \\
\text { Kesehatan }\end{array}$ & \multicolumn{1}{c}{$\begin{array}{c}\text { Total Asset } \\
\text { (dalam ribuan) }\end{array}$} & $\begin{array}{c}\text { Persentase } \\
(\%)\end{array}$ & $\begin{array}{c}\text { Laba } \\
\text { (dalam ribuan) }\end{array}$ & $\begin{array}{c}\text { Jumlah } \\
\text { LPD }\end{array}$ & $\begin{array}{c}\text { Persentase } \\
(\%)\end{array}$ \\
\hline 1 & Sehat & 13.667 .498 .612 & 73,99 & 458.518 .983 & 865 & 60,36 \\
2 & Cukup Sehat & 2.978 .580 .349 & 16,12 & 75.963 .370 & 241 & 16,82 \\
3 & Kurang Sehat & 1.635 .182 .267 & 8,85 & 27.496 .215 & 120 & 8,37 \\
4 & Tidak Sehat & 189.434 .650 & 1,03 & 2.167 .482 & 57 & 3,98 \\
5 & Tidak Beroperasi & 1.243 .400 & 0,01 & 41.680 & 150 & 10,47 \\
\hline & JUMLAH & $\mathbf{1 8 . 4 7 1 . 9 3 9 . 2 7 8}$ & $\mathbf{1 0 0 , 0 0}$ & $\mathbf{5 6 4 . 1 8 7 . 7 3 0}$ & $\mathbf{1 . 4 3 3}$ & $\mathbf{1 0 0 , 0 0}$ \\
\hline
\end{tabular}

Sumber: LPLPD Provinsi Bali, 2018

Pembahasan berikut akan menyajikan hasil pengukuran kinerja sosial LPD besar di Bali. Pengukuran ini dilakukan melalui perhitungan skor pada kuesioner yang diberikan dan diisi oleh prajuru (pengelola/pengurus) dan panureksa (pengawas). Dari hasil pengukuran tersebut akan didapatkan skor total kinerja sosial untuk masing-masing LPD. Semakin besar nilai skor maka semakin baik kinerja sosialnya. Model pengukuran ini tidak mengklasifikasi LPD berdasarkan nilai skor (sangat baik, baik, cukup atau kurang) namun lebih menekankan penyajian informasi pada kinerja sosial berdasarkan dimensi pengukuran. Skor pada masingmasing dimensi akan dibandingkan dan dari hasil perbandingan ini akan diketahui, pada dimensi mana LPD memiliki kelemahan atau keunggulan.

Dimensi pertama kinerja sosial adalah dimensi sasaran dan jangkauan. dimensi ini mengukur target sasaran dan jangkauan layanan LPD yang terdiri dari tiga kriteria yakni, (1) sasaran geografis, (2) sasaran individu dan (3) metode pro-poor. LPD didirikan tidak hanya untuk melayani masyarakat mampu, namun lebih dari itu harus juga memperhatikan anggota masyarakat yang miskin dan berpenghasilan rendah serta tidak dapat mengakses layanan keuangan konvensional.

Dimensi kedua adalah dimensi produk dan layanan: dimensi ini mengukur dan menilai produk dan layanan yang diberikan, dalam dimensi ini terdapat tiga kriteria yakni (1) cakupan layanan (2) kualitas layanan dan (3) inovasi dan layanan non-keuangan. Menyediakan produk dan layanan berkualitas merupakan keharusan LPD, namun produk dan layanan ini juga harus dapat mengakomodasi kebutuhan semua lapisan masyarakat secara adil. Kualitas dan inovasi merupakan hal penting dalam membuat terobosan produk dan layanan yang sesuai dengan kebutuhan masyarakat.

Dimensi manfaat bagi anggota/nasabah mengukur manfaat ekonomi dan sosial layanan LPD kepada nasabah atau klien dan juga komunitas serta masyarakat adat dimana LPD beroperasi. Tiga kriteria pengukuran pada dimensi ini adalah (1) manfaat ekonomis, (2) partisipasi anggota dan (3) modal sosial/pemberdayaan anggota. Selain manfaat secara ekonomis, LPD diharapkan dapat mengembangkan penguatan jaringan sosial, membangun kapasitas dan kekuatan ekonomi anggota dan melibatkan anggota dalam pengembangan ekonomi desa.

Dimensi terakhir atau keempat adalah dimensi tanggungjawab sosial. Dalam dimensi ini akan diukur tingkatan tanggung jawab sosial LPD berdasarkan tiga kriteria yaitu (1) tanggungjawab sosial pada karyawan (2) tanggungjawab sosial pada anggota/nasabah dan (3) tanggungjawab sosial pada masyarakat dan lingkungan hidup. LPD diharapkan memiliki komitmen pada tanggungjawab sosial yang diembannya. Komitmen bahwa lembaga akan 
selalu mengedepankan akuntabilitas dan meyakinkan tidak ada dampak negatif dari aktivitas yang dilakukan. Dampak negatif tidak hanya bagi masyarakat namun juga bagi lingkungan hidup.

Pengukuran kinerja sosial dilakukan pada 38 LPD besar yang tersebar di seluruh kabupaten dan kota di Provinsi Bali. Sebanyak 5 lembaga tidak mengembalikan kuesioner atau tidak mengisi sehingga tersisa 33 LPD yang diukur kinerja sosialnya. LPD dengan total aset diatas Rp 100 Milyar terbanyak ada di kabupaten Badung yakni sebanyak 17 lembaga, disusul kota Denpasar dan kabupaten Gianyar masing-masing 7 lembaga. Kabupaten Buleleng memiliki 4 LPD dengan kategori besar tersebut sedangkan di kabupaten Tabanan terdapat 2 LPD serta kabupaten Karangasem dengan 1 buah LPD. Wilayah yang merupakan pusat industri pariwisata Bali (Badung, Denpasar dan Gianyar) juga merupakan pusat ekonomi di Provinsi Bali, sehingga dapat dimaklumi LPD pada wilayah-wilayah tersebut memiliki pasar yang lebih baik dengan pertumbuhan ekonomi yang cukup tinggi.

Tabel 3. Skor Kinerja Sosial LPD besar di Bali Tahun 2017

\begin{tabular}{|c|c|c|c|c|c|c|}
\hline No & Nama LPD & $\begin{array}{c}\text { Dimensi } \\
\text { Sasaran dan } \\
\text { Jangkauan }\end{array}$ & $\begin{array}{c}\text { Dimensi } \\
\text { Produk \& } \\
\text { Layanan } \\
\end{array}$ & $\begin{array}{c}\text { Dimensi } \\
\text { Manfaat bagi } \\
\text { Nasabah } \\
\end{array}$ & $\begin{array}{c}\text { Dimensi } \\
\text { Tanggung Jwb } \\
\text { Sosial } \\
\end{array}$ & $\begin{array}{l}\text { Total } \\
\text { Skor }\end{array}$ \\
\hline 1 & Kuta & 4 & 7 & 13 & 22 & 46 \\
\hline 2 & Pecatu & 6 & 15 & 18 & 16 & 55 \\
\hline 3 & Jimbaran & 15 & 19 & 17 & 21 & 72 \\
\hline 4 & Kerobokan & 9 & 17 & 17 & 21 & 64 \\
\hline 5 & Bualu & 5 & 14 & 15 & 23 & 57 \\
\hline 6 & Sumber Kima & 1 & 10 & 10 & 15 & 36 \\
\hline 7 & Padang Tegal & 11 & 17 & 13 & 19 & 60 \\
\hline 8 & Seminyak & 2 & 15 & 7 & 20 & 44 \\
\hline 9 & Kesiman & 6 & 17 & 13 & 22 & 58 \\
\hline 10 & Peliatan & 10 & 21 & 18 & 22 & 71 \\
\hline 11 & Pejarakan & 3 & 14 & 10 & 14 & 41 \\
\hline 12 & Anturan & 18 & 17 & 17 & 21 & 73 \\
\hline 13 & Tanjung Benoa & 3 & 13 & 14 & 21 & 51 \\
\hline 14 & Canggu & 11 & 18 & 18 & 24 & 71 \\
\hline 15 & Padang Sambian & 5 & 12 & 12 & 21 & 50 \\
\hline 16 & Tukad Mungga & 11 & 11 & 9 & 12 & 43 \\
\hline 17 & Kampial & 6 & 18 & 10 & 17 & 51 \\
\hline 18 & Intaran & 2 & 9 & 8 & 12 & 31 \\
\hline 19 & Mas & 8 & 19 & 15 & 19 & 61 \\
\hline 20 & Tegal & 7 & 17 & 7 & 19 & 50 \\
\hline 21 & Mambal & 11 & 13 & 9 & 18 & 51 \\
\hline 22 & Panjer & 4 & 14 & 8 & 17 & 43 \\
\hline 23 & Bedha & 7 & 18 & 14 & 21 & 60 \\
\hline 24 & Ketewel & 12 & 16 & 15 & 20 & 63 \\
\hline 25 & Ubung & 7 & 18 & 12 & 22 & 59 \\
\hline 26 & Beraban & 6 & 15 & 13 & 19 & 53 \\
\hline 27 & Mengwi & 4 & 17 & 12 & 22 & 55 \\
\hline 28 & Kepaon & 5 & 18 & 14 & 23 & 60 \\
\hline 29 & Singakerta & 13 & 16 & 18 & 23 & 70 \\
\hline 30 & Celuk & 6 & 16 & 14 & 20 & 56 \\
\hline 31 & Sangeh & 11 & 11 & 16 & 15 & 53 \\
\hline 32 & Sibang Kaja & 6 & 15 & 12 & 19 & 52 \\
\hline \multirow[t]{4}{*}{33} & Tuban & 10 & 17 & 19 & 23 & 69 \\
\hline & Rata-rata & 7 & 15 & 13 & 19 & 55 \\
\hline & Maksimal Skor & 28 & 25 & 25 & 24 & 102 \\
\hline & Pencapaian & $25 \%$ & $63 \%$ & $53 \%$ & $83 \%$ & $55 \%$ \\
\hline
\end{tabular}

Sumber: Data Diolah, 2018

Hasil pengukuran kinerja sosial disajikan pada Tabel 3. Tabel tersebut menyajikan skor kinerja sosial keseluruhan dan juga skor per dimensi. Secara keseluruhan, rata-rata skor kinerja sosial LPD yang menjadi sampel adalah 56 poin. Skor kinerja sosial tertinggi dicapai oleh LPD Jimbaran dengan skor 72 dan terendah adalah LPD Intaran dengan skor 31. 
Maksimal skor kinerja sosial yang dapat dicapai adalah 102. Jika dibandingkan dengan maksimal skor tersebut, rata-rata skor kinerja sosial LPD besar di Bali hanya mencapai 55\%. Hal ini tidak dapat dikatakan terlalu rendah, namun juga belum mencapai skor yang optimal. Kinerja sosial LPD besar di Bali masih sangat perlu ditingkatkan dengan memfokuskan pada dimensi kinerja yang masih rendah.

Berdasarkan skor per dimensi, skor rata-rata tertinggi ada pada dimensi tanggung jawab sosial dengan nilai 19 poin dan terendah pada dimensi sasaran dan jangkauan dengan nilai 7 poin. LPD besar di Bali sangat lemah pada dimensi sasaran dan jangkauan, dengan pencapaian hanya $25 \%$ dari maksimal skor yang dapat dicapai. Pencapaian kinerja pada dimensi produk dan layanan serta dimensi manfaat bagi nasabah memiliki pencapaian skor yang cukup baik dengan masing-masing mencapai $63 \%$ dan 53\% dari maksimal skor yang dapat dicapai. Kekuatan kinerja sosial LPD terlihat pada dimensi tanggung jawab sosial yang mencapai $83 \%$ dari maksimal skor. Pada Gambar 1 memang terlihat ketimpangan kinerja sosial antar dimensi, dimana kecondongan kinerja sosial yang kuat terlihat pada dimensi tanggung jawab sosial dan kinerja yang lemah pada dimensi sasaran dan jangakuan.

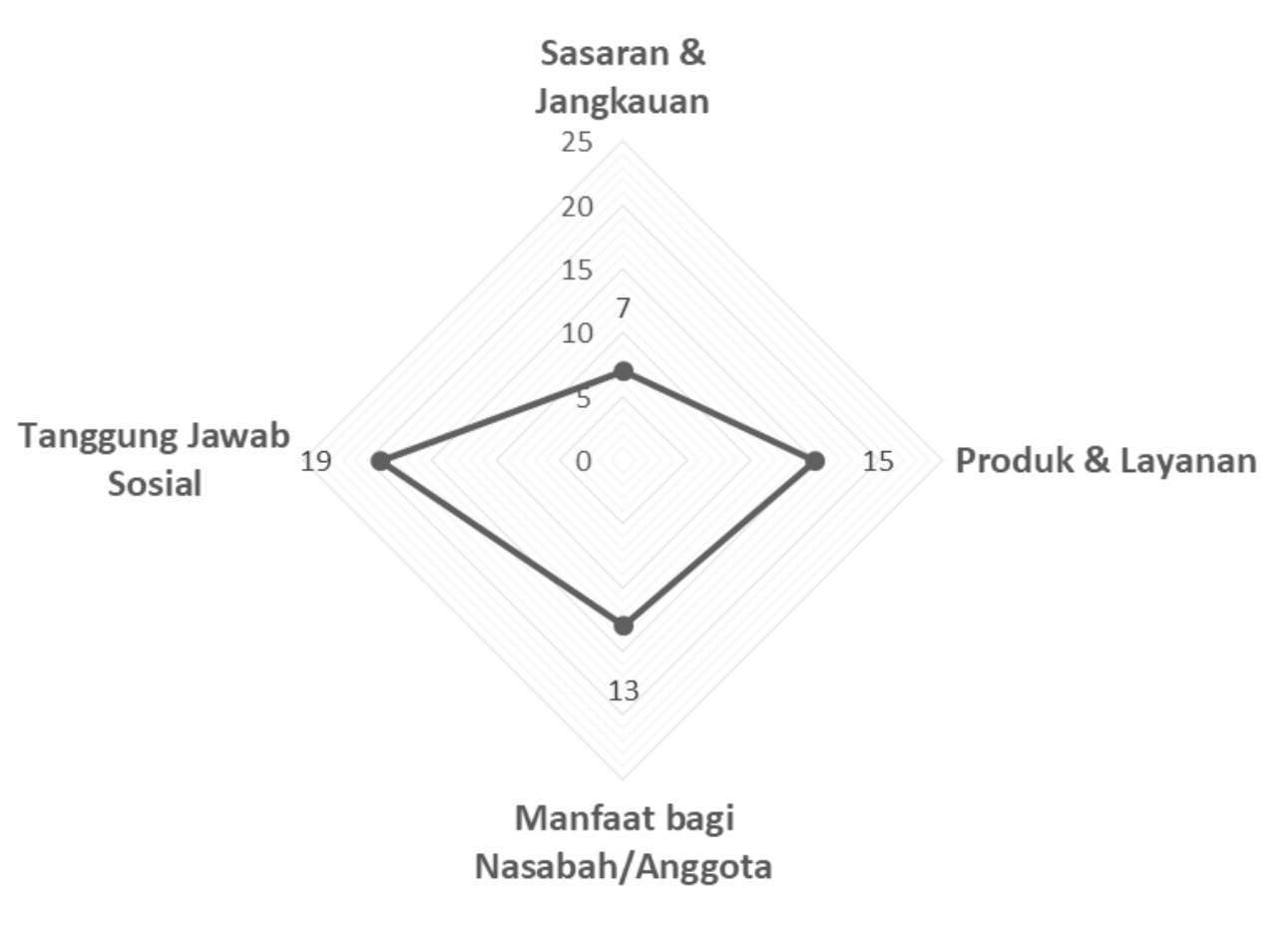

\section{Gambar 1. Kinerja Sosial LPD Berdasarkan Dimensi Pengukuran}

Gambar 2 menyajikan pencapaian kinerja sosial per kriteria pengukuran. Pencapaian ini disajikan berdasarkan persentase capaian tiap kriteria jika dibandingkan dengan maksimal skor yang dapat dicapai. Kriteria tanggung jawab sosial pada nasabah/anggota memiliki pencapaian $100 \%$, yang merupakan pencapaian kriteria tertinggi. Kriteria-kriteria pada dimensi tanggung jawab sosial memiliki pencapaian skor yang tinggi. Capaian skor rendah ada pada kriteria sasaran geografis, sasaran individu dan metode pro-poor yang merupakan kriteria pada dimensi sasaran dan jangkauan. Kriteria pada dimensi produk dan layanan memiliki pencapaian yang cukup dengan pencapaian terendah pada kriteria inovasi dan layanan non keuangan. Pada dimensi manfaat bagi nasabah/anggota, pencapaian tiap kriteria masih dapat 
dikatakan cukup, dengan perhatian harus difokuskan pada kriteria modal sosial/pemberdayaan anggota.

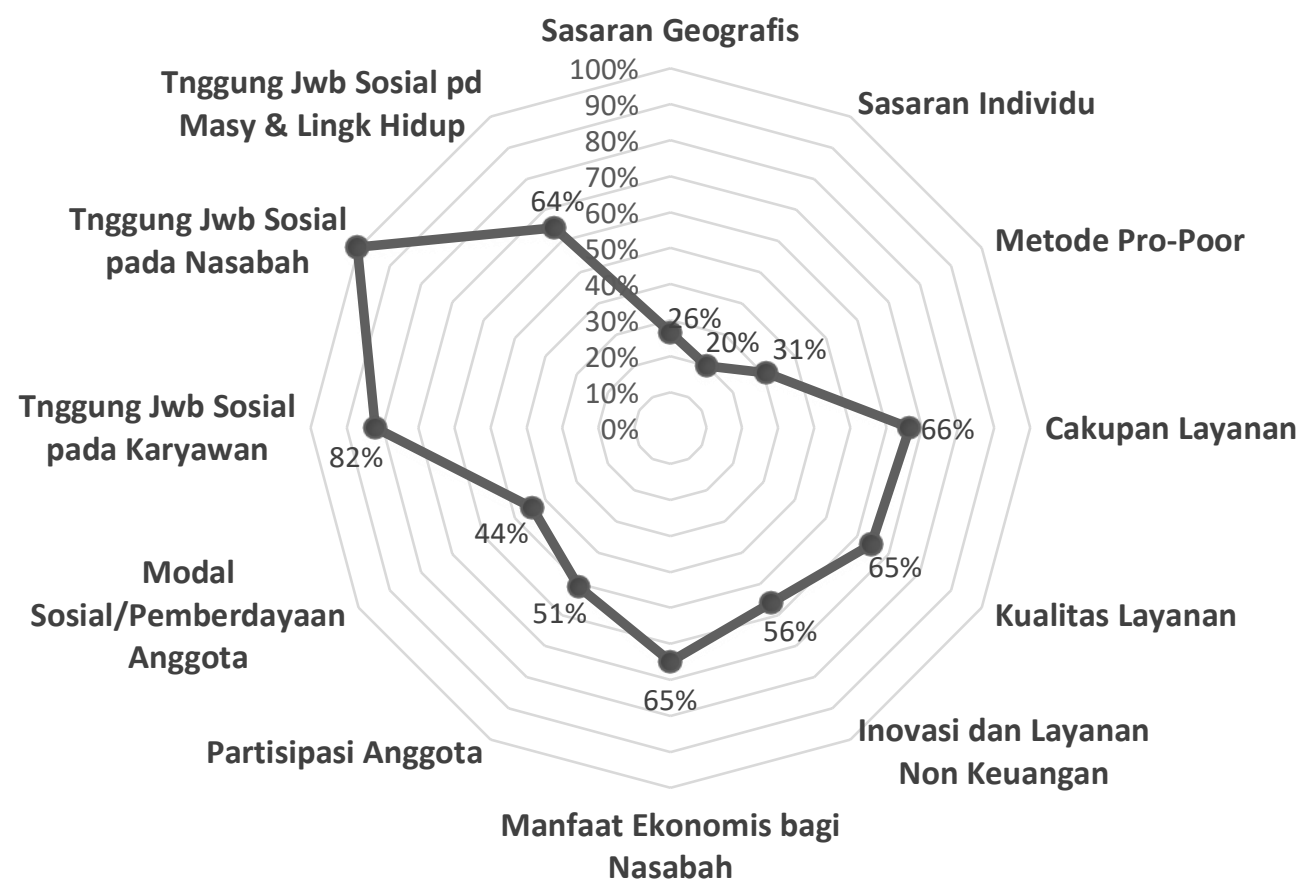

\section{Gambar 2. Kinerja Sosial LPD Berdasarkan Kriteria Pengukuran}

Pengukuran kinerja sosial LPD menunjukkan bahwa, LPD masih sangat perlu meningkatkan kinerja sosialnya. Pencapaian skor kinerja 53\% dari maksimal skor, tidak menunjukkan kinerja yang baik, walaupun bisa dikatakan cukup. Kurangnya data pembanding skor kinerja dari LKM lain di Indonesia cukup menyulitkan untuk melakukan perbandingan capaian penilaian. Model pengukuran Social Performance Indicators (SPI) yang dikembangkan lembaga CERISE juga belum pernah digunakan dalam mengukur kinerja sosial LKM di Indonesia. Hasil pengukuran dengan SPI pada LKM internasional juga cukup sulit didapatkan. Situasi ini menyulitkan dalam melakukan perbandingan kinerja sosial pada industri yang sama.

Hasil pengukuran pada tiap dimensi menunjukkan bahwa dimensi pertama yaitu sasaran dan jangkauan merupakan dimensi kinerja sosial terendah LPD. Ketiga kriteria pada dimensi ini memperoleh skor yang sangat rendah. Kriteria sasaran geografis mengukur kinerja LPD pada hal yang terkait perhatian lembaga pada masyarakat berpenghasilan rendah/miskin dengan pemetaan wilayah serta jangkauan pelayanan. Demikian juga dengan kriteria sasaran individu dan metode pro-poor yang mengukur kinerja berdasarkan dukungan LPD pada masyarakat berpenghasilan rendah atau terpinggirkan. Dimensi ini mengukur kinerja sosial LPD dalam menyasar dan menjangkau masyarakat miskin dan terpinggirkan. Nilai kinerja yang sangat rendah pada dimensi ini disebabkan oleh karena hampir semua LPD besar beroperasi pada wilayah dengan tingkat penghasilan masyarakat yang cukup tinggi, atau dapat dikatakan tidak terdapat penduduk miskin. Jangkauan wilayah operasional LPD yang hanya terbatas pada wilayah desa pakraman saja, juga bisa menjadi penyebab. Dalam upaya meningkatkan kinerja sosial pada dimensi ini, LPD semestinya menaruh perhatian lebih besar pada masyarakat berpenghasilan rendah. Jika di wilayahnya tidak terdapat masyarakat miskin, 
LPD harus lebih aktif melakukan kerjasama dengan LPD lain yang berada pada wilayah dengan tingkat kemiskinan yang cukup tinggi. BKS-LPD yang dalam hal ini merupakan lembaga yang menginisiasi kerjasama antar LPD, harus lebih aktif mempertemukan LPD yang berada pada wilayah tingkat ekonomi yang rendah dengan LPD dengan wilayah tingkat ekonomi tinggi. LPD semestinya dapat menciptakan program-program baik produk maupun layanan yang memberi dukungan pada masyarakat berpenghasilan rendah, sehingga kinerja sosial lembaga dapat ditingkatkan, yang akan bermuara pada peningkatan ekonomi masyarakat golongan tersebut.

Kinerja sosial pada dimensi kedua yakni produk dan layanan sudah cukup baik, dengan pencapaian diatas 50\% dari maksimal skor. Hal ini bisa dicapai karena LPD besar yang menjadi populasi sudah memiliki manajemen pengelolaan lembaga yang baik. Berada pada wilayah dengan tingkat persaingan yang tinggi antar lembaga keuangan juga membuat LPD besar harus menciptakan produk dan memberikan layanan yang bagus serta lebih inovatif agar mampu bersaing. Kriteria pada dimensi ini adalah cakupan layanan, kualitas layanan serta inovasi dan layanan keuangan. Kinerja pada dimensi ini masih bisa ditingkatkan dengan cara lebih inovatif dalam menciptakan produk dan layanan yang berfokus pada kebutuhan sosial krama desa adat dan secara aktif terus meningkatkan kualitas produk dan layanan yang diberikan. Jumlah kantor cabang juga menjadi penilaian pada dimensi ini, sedangkan LPD hanya beroperasi pada wilayah terbatas sehingga kondisi ini tentu juga menurunkan nilai kinerja. Model pengukuran SPI yang digunakan hendaknya dimodifikasi dengan menggunakan elemen pengukuran yang lebih sesuai dengan kondisi LPD.

Hasil pengukuran pada dimensi ketiga yakni manfaat bagi anggota/nasabah menunjukkan kinerja sosial yang cukup. Dua kriteria pada dimensi ini yaitu manfaat ekonomis dan partisipasi anggota/nasabah memiliki pencapaian masing-masing $65 \%$ dan $51 \%$. Pencapaian yang cukup rendah terlihat pada kriteria ketiga yaitu modal sosial/pemberdayaan anggota. LPD harus lebih aktif dalam menciptakan program-program pemberdayaan krama (warga/anggota) desa adat sehingga hal ini dapat menjadi modal sosial yang bagus bagi lembaga. Pemberdayaan wanita, pendampingan untuk peningkatan akses layanan keuangan serta pelibatan warga dalam jaringan ekonomi dan pemerintah merupakan hal yang harus diprioritaskan. Kinerja pada dimensi sosial ini bisa ditingkatkan dengan cara mengidentifikasi manfaat ekonomis LPD bagi krama desa dan juga meningkatkan partisipasi krama di LPD. Manajemen kinerja sosial yang baik dapat diwujudkan dengan melibatkan semua stakeholder dalam pengelolaan lembaga, termasuk transparansi pengelolaan lembaga.

Dimensi keempat yakni tanggung jawab sosial merupakan dimensi dengan kinerja sosial tertinggi. LPD berhasil memenuhi tanggung jawab sosial pada karyawannya, pada nasabah dan juga pada masyarakat dan lingkungan hidup. Perhatian LPD pada karyawannya merupakan salah satu wujud tanggung jawab sosial dan juga hal yang sangat penting, karena semua karyawan merupakan krama desa adat. Menjaga dan melindungi hak nasabah merupakan tanggung jawab LPD pada nasabahnya. Pembagian dua puluh persen laba kepada desa adat dan juga lima persen untuk dana sosial merupakan tanggung jawab sosial pada masyarakat/krama desa dan salah satu hal penting dalam mewujudkan kinerja sosial yang baik. LPD juga diharapkan menciptakan program-program peduli lingkungan hidup dalam upaya menciptakan sustainable economics dan meningkatkan kinerja sosial

\section{SIMPULAN}

Kinerja sosial LPD besar di Bali masih sangat perlu untuk ditingkatkan. Berdasarkan hasil pengukuran pada empat dimensi kinerja sosial, terlihat bahwa LPD sangat lemah pada dimensi sasaran dan jangkauan. Hal ini tidaklah mengherankan karena LPD hanya beroperasi 
di wilayah desa pakraman saja dengan jangkauan terbatas. Kurangnya perhatian LPD pada masyarakat berpenghasilan rendah atau miskin karena wilayah dari LPD besar berada pada wilayah pusat-pusat pariwisata Bali dengan kondisi penghasilan masyarakat yang cukup tinggi. Dimensi kinerja sosial yang paling kuat adalah dimensi tanggung jawab sosial, dimana LPD sudah mampu menjalankan fungsi sosial dengan mengedepankan tanggung jawab sosial baik pada karyawan, krama desa pakraman maupun lingkungan hidup.

LPD diharapkan meningkatkan kinerja sosialnya terutama pada dimensi sasaran dan jangkauan. Hal ini dapat dilakukan dengan cara menjalin kerjasama dengan LPD yang ada di wilayah dengan tingkat penghasilan kecil dan masyarakat dengan ekonomi terbelakang yang masih cukup tinggi. Kerjasama ini dimungkinkan karena saat ini sudah dibentuk BKS-LPD pada tiap kabupaten, sehingga lembaga ini bisa menjadi wadah dalam mengembangkan kerjasama untuk turut serta meningkatkan taraf ekonomi pada krama desa pakraman dengan tingkat penghasilan rendah.

\section{REFERENSI}

Arsyad, L. (2008). Lembaga Keuangan Mikro; Institusi, Kinerja, \& Sustanabilitas. Yogyakarta. Penerbit ANDI.

Baskara, I. G. K. (2013). Lembaga Keuangan Mikro di Indonesia. Buletin Studi Ekonomi.

Bibi, U., Balli, H. O., Matthews, C. D., \& Tripe, D. W. L. (2018). New approaches to measure the social performance of microfinance institutions (MFIs). International Review of Economics and Finance. https://doi.org/10.1016/j.iref.2017.10.010

CGAP (Consultative Group to Assist The Poor). (2007). Beyond Good Intentions: Measuring The Social Performance of Microfinance Institution. CGAP Focus Note No. 41. 